\title{
CONVERSION OF CORN FIBER INTO FUEL ETHANOL
}

\author{
VLADIMÍR ONDÁŠ, HANA NOVANSKÁ, VIERA HORVÁTHOVÁ \\ Department of Biotechnology, University of SS. Cyril and Methodius, J. Herdu 2, \\ Trnava, SK-917 01, Slovak Republic (vladimir.ondas@gmail.com)
}

\begin{abstract}
Corn fiber due to its chemical composition (up to $20 \%$ starch, $50-60 \%$ non-starch polysaccharides) and availability has potential to serve as a substrate for manufacture of various products, including fuel ethanol. This paper deals with assessment of fiber-to-ethanol conversion. The water/dry fiber ratio in suspensions was 10/1. Enzyme liquefaction and saccharification of residual starch in corn fiber was carried out in two steps with thermostable $\alpha$-amylase $\left(20 \mathrm{~min}, 120^{\circ} \mathrm{C}\right)$ and mixture of pullulanase and glucomalyse $\left(24\right.$ hours, $\left.60^{\circ} \mathrm{C}\right)$. Procedures resulted in release of $57.7 \pm 1.6 \mathrm{mg}$ of glucose per gram of dry fiber basis. It responds to the dextrose equivalent expression to $96.7 \pm 2.2 \%$. By fermentation of the starch hydrolysates by yeasts Saccharomyces cerevisiae CCY $-11-3\left(5 \% \mathrm{v} / \mathrm{v}\right.$ inoculum, $28^{\circ} \mathrm{C}, 72$ hours $) 0.48 \mathrm{~g}$ of ethanol per gram of glucose in hydrolysates was obtained. The solids after starch hydrolysis were separated by filtration and processed by acid pretreatment $(0.1 \mathrm{~g}$ of conc. $\mathrm{HCl} / \mathrm{g}$ of biomass $/ 5 \mathrm{ml}$ of water, $\left.120^{\circ} \mathrm{C}, 20 \mathrm{~min}\right)$ with subsequent enzyme hydrolysis $\left(24\right.$ hours, $\left.60^{\circ} \mathrm{C}\right)$ by the multienzyme preparations containing cellulases and hemicellulases. Overall yield of reducing sugars after these two steps was $740.7 \pm 3.9 \mathrm{mg} / \mathrm{gram}$ of dry corn fiber basis. Fermentation of lignocellulosic hydrolysates by yeasts Pichia stipitis CCY-39-50-1 and Candida shehatea CCY-29-68-4 (in both cases 5\% v/v inoculum, $28^{\circ} \mathrm{C}, 72$ hours) resulted in 0.38 and $0.12 \mathrm{~g}$ of ethanol per gram of reducing sugars. The results indicate that applied pretreatment methods and used microorganisms are able to produce ethanol from corn fiber.
\end{abstract}

Key words: corn fiber, enzyme hydrolysis, acid pretreatment, pentose- and hexose-fermenting yeasts

\section{Introduction}

Corn fiber is a potential raw material for the production of various products, including fuel ethanol, because it is available in countries in which corn grains are processed (MOSIER et al., 2005; ATKIN, et al., 2008; NOUREDDINI et al., 2009). It is obtained in the process of wet milling of corn. Corn fiber, similar to other lignocellulosic materials is the complex of polysaccharides ( $35 \%$ hemicelluloses, $20 \%$ cellulose, up to $20 \%$ starch) and lignin. The main component of corn fiber is the outer corn grain layer - pericarp and residual part of starchy endosperm (GÁSPÁR et al., 2007). The first step of bioethanol production is enzymatic saccharification, in which polysaccharides are converted to monomeric sugars. In contrast to starch or cellulose, containing only hexose - glucose, hemicelluloses contain also pentoses, like xylose and arabinose. In the second step yeasts are used for the fermentation of these sugars (RÉCZEY et al., 1996, BALLESTEROS et al., 2004; PALMAROLA-ADRADOS et al., 2005). The most used pentose-fermenting microorganisms are various yeasts like Pichia stipitis, Candida shehatea, Pachysolen tannophilus, but also other strains of this species are able to ferment xylose (ZHAO et al., 2005; MARIS et al., 2006). Beside naturally occurring pentose-ferment yeasts, also genetically improved $E$. coli strains or Zymomonas mobilis strains are able to convert pentose to ethanol (JARBOE et al., 2007). 
Conversion of the starch along with the lignocellulosic components in the corn fiber would increase ethanol yields from corn wet mill by 13\% (GROHMANN and BOTHAST, 1997) and is promising if the value of the corn fiber as an animal feed product is not severely affected (SCHELL et al., 2004).

The aim of this study was to investigate the possibility of corn fiber to ethanol conversion by traditional methods of lignocellulose substrate processing.

\section{Materials and methods}

\subsection{Materials}

Microbial strains Saccharomyces cerevisiae CCY-11-3, Pichia stipitis CCY 39-50-1 and Candida shehatea CCY 29-68-4 were obtained from The Culture Collection of Yeasts at Institute of Chemistry (Slovak Academy of Sciences, Slovakia), subcultured on slant agar media and stored in a refrigerator at a temperature about $4{ }^{\circ} \mathrm{C}$. Corn fiber was received from Amylum Slovakia s.r.o (Boleráz, Slovakia) and stored at $-20^{\circ} \mathrm{C}$. The following commercial enzymes were used: thermostable $\alpha-$ amylase (Termamyl 120L), glucoamylase (AMG 300L), thermostable pullulanase (Promozyme D2), cellulose (Celluclast 1,5L) and $\beta$-glucosidase (Viscozyme L). All enzymes were obtained from Novozymes (Denmark).

\subsection{Corn fiber destarching}

A $10 \%(\mathrm{w} / \mathrm{w})$ non-ground corn fiber dry matter aqueous solution was prepared. Thermostable $\alpha$-amylase for starch liquefaction $(0.3 \mu \mathrm{l} / \mathrm{g}$ starch $)$ was added in two steps and the mixture was boiled at up to $120^{\circ} \mathrm{C}$ for $20 \mathrm{~min}$. After cooling to about $60^{\circ} \mathrm{C}$ was glucoamylase $(0.8 \mu \mathrm{l} / \mathrm{g}$ starch $)$ and thermostable pullulanase $(7.2 \mu \mathrm{l} / \mathrm{g}$ starch) added and incubated at $60^{\circ} \mathrm{C}$ for 24 hours. The solids were recovered by filtration. Schematic view of this process in the context of other processes is depicted in Fig. 1.

\subsection{Pretreating of destarched corn fiber with hydrochloric acid}

Solids after destarching were mixed with $5 \mathrm{ml}$ of water and $0.1 \mathrm{~g}$ of concentrated hydrochloric acid. Mixture was heated in a pressure device at $120^{\circ} \mathrm{C}$ for 20 minutes. After cooling to room temperature, the solids were recovered by filtration. Schematic view of this process in the context of other processes is illustrated in Fig. 1.

\subsection{Enzymatic hydrolysis of cellulose in pretreated corn fiber}

The mixture of cellulolytic enzymes $(119 \mu \mathrm{l} / \mathrm{g}$ dry matter of lignocellulose $)$ and $\beta$ glucosidase $(595 \mu \mathrm{l} / \mathrm{g}$ dry matter of lignocellulose) was inoculated to $5 \%$ acetate buffer solution of destarched and pretreated solids of corn fiber. The reaction was allowed to proceed for 24 hours at $60^{\circ} \mathrm{C}$ and stirring at speed rate $120 \mathrm{rpm}$. Schematic view of this process in the context of other processes is shown in Fig. 1. 


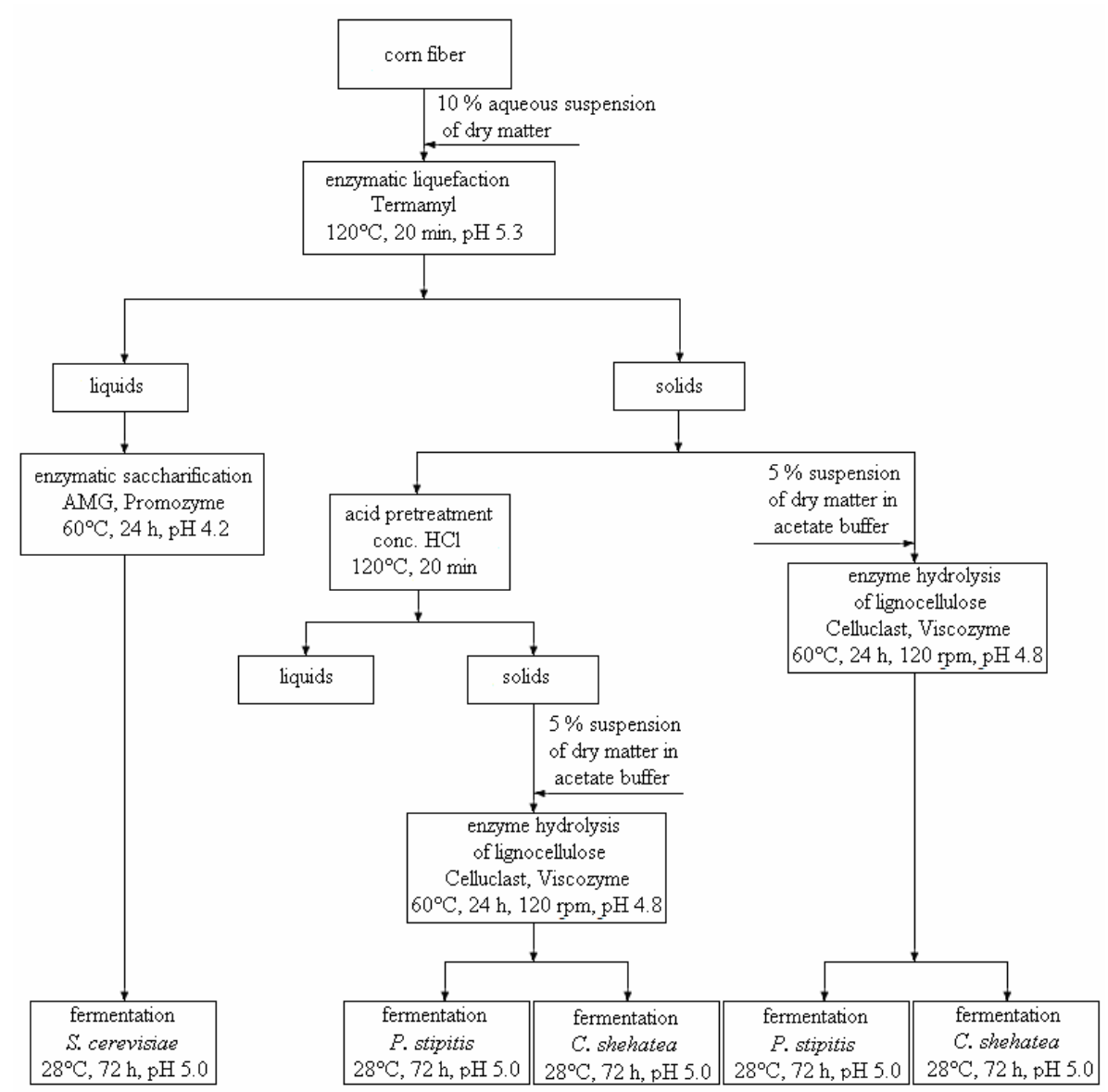

Fig. 1. Schematic view of processes involved in the processing of corn fiber to ethanol.

\subsection{Fermentation}

Liquid hydrolysate from corn fiber destarching was inoculated with $5 \%$ inoculum of yeasts Saccharomyces cerevisiae, fermentation medium components were added and $\mathrm{pH}$ was adjusted to 5.0. Liquid hydrolysate from enzyme hydrolysis of destarched and pretreated corn fiber was inoculated with $5 \%$ inoculum of yeasts Pichia stipitis or Candida shehatea, fermentation medium components were added and $\mathrm{pH}$ was adjusted to 5.0. Fermentation was carried out at $28^{\circ} \mathrm{C}$ and lasts 72 hours. Schematic view of this process in the context of other processes is depicted in Fig. 1.

\subsection{Analytical procedures}

The dry matter content of corn fiber, destarched corn fiber and pretreated corn fiber was determined by drying of the sample at $105^{\circ} \mathrm{C}$. Glucose content was determined 
using BIOLA TEST GLUKOSA GOD 1500 (Lachema, Czech Republic) and reducing sugars were determined using dinitrosalicylic acid (DNS). Analyses of glucose, maltose, maltotriose and oligosaccharides were performed by high performance liquid chromatography (HPLC) with an HPX-87C column (Bio-Rad Laboratories, Hercules, USA) at $80^{\circ} \mathrm{C}$ with water as the mobile phase at a flow rate of $0.5 \mathrm{ml} / \mathrm{min}$.

\section{Results and discussion}

Destarching of corn fiber with enzymes was carried out in two steps using thermostable $\alpha$-amylase for liquefaction and mixture of pullulanase and glucoamylase for saccharification. Kinetics of saccharification is shown in Table 1. Results are averages of three determinations

Table 1. Saccharification kinetics of liquefied starch in suspension with $10 \%$ content of corn fiber dry matter.

\begin{tabular}{|c|c|c|c|c|c|}
\hline \multirow{2}{*}{ Hour } & \multicolumn{2}{|c|}{ Reducing sugars } & \multicolumn{3}{|c|}{ Glucose } \\
\hline & $\begin{array}{c}\mathrm{mg} / \mathrm{ml} \\
\text { hydrolysate }\end{array}$ & $\begin{array}{c}\mathrm{mg} / \mathrm{g} \\
\text { dry matter }\end{array}$ & $\begin{array}{c}\mathrm{mg} / \mathrm{ml} \\
\text { hydrolysate }\end{array}$ & $\begin{array}{c}\mathrm{mg} / \mathrm{g} \\
\text { dry matter }\end{array}$ & $\begin{array}{l}\text { DE } \\
(\%)\end{array}$ \\
\hline $\mathbf{0}$ & $3.0 \pm 0.2$ & $24.4 \pm 1.6$ & $0.6 \pm 0.05$ & $5.2 \pm 0.4$ & $8.7 \pm 0.3$ \\
\hline 2 & $5.1 \pm 0.1$ & $41.8 \pm 0.8$ & $4.4 \pm 0.1$ & $35.8 \pm 0.8$ & $59.9 \pm 1.5$ \\
\hline 4 & $5.8 \pm 0.2$ & $47.2 \pm 1.6$ & $4.6 \pm 0.1$ & $37.8 \pm 0.8$ & $63.3 \pm 1.6$ \\
\hline 6 & $6.1 \pm 0.1$ & $50.0 \pm 0.8$ & $5.5 \pm 0.2$ & $44.5 \pm 1.6$ & $74.5 \pm 1.6$ \\
\hline 8 & $6.6 \pm 0.1$ & $53.8 \pm 0.8$ & $6.4 \pm 0.1$ & $52.3 \pm 0.8$ & $90.0 \pm 1.9$ \\
\hline 24 & $9.6 \pm 0.1$ & $78.5 \pm 0.8$ & $7.1 \pm 0.2$ & $57.7 \pm 1.6$ & $96.7 \pm 2.2$ \\
\hline
\end{tabular}

$\mathrm{DE}(\%)=$ dextrose equivalent

In the first eight hours the dextrose equivalent achieved $90 \%$, and in the next sixteen hours it rose to almost $97 \%$. Similar time course of saccharification is described in the work of LEATHERS (2003). Glucose represents about $64.6 \%$ of all sugars in hydrolysate, maltotriose $17.2 \%$ and last $18 \%$ other oligosaccharides. We supposed that lower proportion of glucose was caused by reduced availability of starch as a result of the particle size of substrate. Destarching of corn fiber leads to better access of pretreatment or hydrolysing agents to non-starch polysaccharides or other substrates.

Because corn fiber contains about $35 \%$ of hemicelluloses, $18 \%$ of cellulose and $8 \%$ of lignin, it is necessary to pretreat it before enzymatic hydrolysis of polysaccharides to achieve the maximum release of fermentable sugars. Acid hydrolysis is one of the possible pretreatment ways (SHIBANUMA et al., 1999; SAHA, 2003; NOUREDDINI et al., 2009). In our experiments $1 \mathrm{~g}$ of destarched corn fiber was supplemented with $0.1 \mathrm{~g}$ of concentrate hydrochloric acid and $5 \mathrm{ml}$ of water. The mixture was heated in a pressure device at up to $120^{\circ} \mathrm{C}$ for 20 minutes. After heating the device was 
allowed to cool to room temperature and solids were separated from liquid hydrolysate by filtration. Obtained results are listed in Table 2. Results are averages of three determinations.

Table 2. Concentration of reducing sugars and glucose after pretreatment of destarched corn fiber with hydrochloric acid.

\begin{tabular}{lcccc}
\hline & \multicolumn{2}{c}{ Reducing sugars } & \multicolumn{2}{c}{ Glucose } \\
\cline { 2 - 5 } & $\begin{array}{c}\mathbf{m g} / \mathbf{m l} \\
\text { hydrolysates }\end{array}$ & $\begin{array}{c}\mathbf{m g} / \mathbf{m l} \\
\text { hydrolysates }\end{array}$ & $\begin{array}{c}\mathbf{m g} / \mathbf{m l} \\
\text { hydrolysates }\end{array}$ & $\begin{array}{c}\mathbf{~ m g / g} \\
\text { dry } \mathbf{~ m a t t e r}\end{array}$ \\
\hline Hydrochloric acid & $35.2 \pm 1.3$ & $587 \pm 3$ & $7.0 \pm 0.4$ & $117 \pm 1$ \\
\hline
\end{tabular}

Because most of the pretreatment strategies do not lead to complete hydrolysis of polysaccharides, an important step in processing any lignocellulosic material is the enzymatic hydrolysis of cellulose or hemicelluloses or both polysaccharides. In addition, enzymatic processes are carried out under mild conditions and thus lower consumption of energy. The risk of fermentation inhibitors creation is also minimal. Processing of destarched corn fiber with cellulytic and hemicellulytic enzymes in our experiments lasts 24 hours and temperature was maintained at $60^{\circ} \mathrm{C}$. The results are summarized in Table 3 and are averages of three determinations.

Table 3. Concentration of reducing sugars and glucose after enzymatic hydrolysis of destarched corn fiber and destarched and pretreated corn fiber.

\begin{tabular}{ccccc}
\hline \multirow{2}{*}{ Substrate } & \multicolumn{2}{c}{ Reducing sugars } & \multicolumn{2}{c}{ Glucose } \\
\cline { 2 - 5 } & $\begin{array}{c}\mathbf{m g} / \mathbf{m l} \\
\text { hydrolysates }\end{array}$ & $\begin{array}{c}\mathbf{m g} / \mathbf{m l} \\
\text { hydrolysates }\end{array}$ & $\begin{array}{c}\mathbf{~ m g / m l} \\
\text { hydrolysates }\end{array}$ & $\begin{array}{c}\mathbf{~ m g / g} \\
\text { dry matter }\end{array}$ \\
\hline $\begin{array}{c}\text { Destarched } \\
\text { corn fiber }\end{array}$ & $3.7 \pm 0.1$ & $61.7 \pm 2.2$ & $1.5 \pm 0.1$ & $25.8 \pm 0.9$ \\
$\begin{array}{c}\text { Destarched and } \\
\text { pretreated corn } \\
\text { fiber }\end{array}$ & $8.2 \pm 0.3$ & $154 \pm 1$ & $2.81 \pm 0.1$ & $52.9 \pm 0.3$ \\
\hline
\end{tabular}

By HPLC (results provided by Amylum Slovakia s.r.o., Boleráz) was determined that oligosaccharides represent more than $60 \%$ of all sugars in enzyme hydrolysates of destarched and pretreated corn fiber. Other saccharides were maltose and maltotriose.

In next part of the research fermentation of starch and lignocellulosic hydrolysates prepared from corn fiber was carried out. For the fermentation of starch hydrolysates yeasts Saccharomyces cerevisiae were used and for lignocellulosic hydrolysates yeasts Pichia stipitis and Candida shehatea were used. Fermentation conditions were the

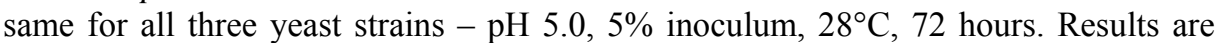
shown in Table 4 (starch hydrolysates), Table 5 and Table 6 (lignocellulosic hydrolysates). 
Table 4. Yield of ethanol after fermentation by Saccharomyces cerevisiae of starch hydrolysates with $10 \%$ content of corn fiber dry matter.

\begin{tabular}{|c|c|c|c|c|}
\hline \multirow[b]{2}{*}{ Substrate } & \multicolumn{3}{|c|}{ Amount of waterless ethanol } & \multirow[b]{2}{*}{$\begin{array}{c}\text { Conversion } \\
{[\%]^{*}}\end{array}$} \\
\hline & $\begin{array}{c}\mathrm{g} / 100 \mathrm{ml} \\
\text { fermentation } \\
\text { medium }\end{array}$ & $\begin{array}{c}\text { g/g } \\
\text { glucose }\end{array}$ & $\begin{array}{c}\text { g/g } \\
\text { dry matter }\end{array}$ & \\
\hline Corn fiber & 0.56 & 0.48 & 0.03 & 94.2 \\
\hline
\end{tabular}

* The degree of conversion is value relative to the maximum theoretical yield of ethanol $(0.51 \mathrm{~g}$ ethanol from $1 \mathrm{~g}$ of glucose) (BALLESTEROS et al., 2004).

BURA et al. (2002), for the fermentation of starch from corn fiber also used yeasts Saccharomyces cerevisiae, but with substrate pretreated by $\mathrm{SO}_{2}$ steam explosion. In those conditions yeasts Saccharomyces cerevisiae converted saccharides in hydrolysates with efficiency from 90 to $96 \%$. Also our conversion efficiency falls within this range.

Table 5. Yield of ethanol after fermentation by Pichia stipitis and Candida shehatae of lignocellulosic hydrolysate of destarched corn fiber pretreated with hydrochloric acid.

\begin{tabular}{ccccc}
\hline \multirow{2}{*}{ Microorganism } & \multicolumn{3}{c}{ Amount of waterless ethanol } & $\begin{array}{c}\text { Conversion } \\
{[\%]^{*}}\end{array}$ \\
\cline { 2 - 5 } & $\begin{array}{c}\text { g/ 100 } \mathbf{~ m l} \\
\text { fermentation } \\
\text { medium }\end{array}$ & $\begin{array}{c}\text { g/g } \\
\text { reducing } \\
\text { sugars }\end{array}$ & $\begin{array}{c}\text { g/g } \\
\text { dry matter }\end{array}$ & \\
\hline Pichia stipitis & 0.16 & 0.44 & 0.02 & 84.2 \\
Candida shehatae & 0.05 & 0.14 & 0.01 & 28.4 \\
\hline
\end{tabular}

* The degree of conversion is value relative to the maximum theoretical yield of ethanol $(0.51 \mathrm{~g}$ ethanol from $1 \mathrm{~g}$ of glucose) (BALLESTEROS et al., 2004).

Table 6. Yield of ethanol after fermentation by Pichia stipitis and Candida shehatea of hydrolysate of corn fiber pretreated by acid prehydrolysis and enzymatic hydrolysis.

\begin{tabular}{ccccc}
\hline Microorganism & \multicolumn{3}{c}{ Amount of waterless ethanol } & $\begin{array}{c}\text { Conversion } \\
{[\%]^{*}}\end{array}$ \\
\cline { 2 - 5 } & $\begin{array}{c}\text { g/ } \mathbf{1 0 0} \mathbf{~} \mathbf{~} \\
\text { fermentation } \\
\text { medium }\end{array}$ & $\begin{array}{c}\text { g/g } \\
\text { reducing } \\
\text { sugars }\end{array}$ & $\begin{array}{c}\text { g/g } \\
\text { dry matter }\end{array}$ & \\
\hline Pichia stipitis & 0.85 & 0.38 & 0.09 & 73.9 \\
Candida shehatea & 0.27 & 0.12 & 0.03 & 22.9 \\
\hline
\end{tabular}

* The degree of conversion is value relative to the maximum theoretical yield of ethanol $(0.51 \mathrm{~g}$ ethanol from $1 \mathrm{~g}$ of glucose) (BALLESTEROS et al., 2004). 
We have to state that fermentation of destarched corn fiber hydrolysates by Candida shehatea was efficient not enough. One of the problems causing such low values may also be poor adaptation of yeast strain Candida shehatea CCY 29-68-4 to the fermentation conditions such as temperature, $\mathrm{pH}$, presence of inhibitors, the composition of the fermentation medium or the need for aeration. To define optimal conditions for the strain of Candida shehatea CCY 29-68-4 undertaking of further experiments is needed.

\section{Conclusions}

Although agricultural residues are plentiful and readily accessible, improved methods are needed for their conversion to fermentable sugars and subsequently to ethanol or other value-added products. This is also a case of pretreatment method based on acid hydrolysis at lower temperature (under $150^{\circ} \mathrm{C}$ ). Also using of pentosefermenting yeasts, like Pichia stipitis and Candida shehatea needs very careful determination of fermentation conditions.

Acknowledgments: This research was supported by the Slovak Research and Development Agency within the Project APVV LPP-0251-07.

\section{References}

ATKIN, D.E., RIGSBY, L.L.: Corn fiber: Structure, composition, and response to enzymes for fermentable sugars and coproducts. Appl. Biochem. Biotechnol., 144, 2008, 59-68.

BALlESTEROS, M., OLIVE, J.M., NEGRO, M.J., MANZANARES, P., BALLESTEROS, I.: Ethanol from lignocellulosic materials by a simultaneous saccharification and fermentation process (SFS) with Kluyveromyvces marxianus CECT 10875. Process Biochem., 39, 2004, 1843-1848.

BURA, R., MANSFIELD, S.D., SADDLER, J.N., BOTHAST, R.J.: $\mathrm{SO}_{2}$-catalyzed steam explosion of corn fiber to ethanol production. Appl. Biochem. Biotechnol., 98, 2002, 59-66.

GÁSPÁR, M., KÁLMÁN, G., RÉCZEY, K.: Corn fiber as a raw material for hemicellulose and ethanol production. Process Biochem., 42, 2007, 1135-1139.

GROHMANN, K., BOTHAST, R.: Saccharification of corn fiber by combined treatment with dilute sulphuric acid and enzymes. Process Biochem., 32, 1997, 405-415.

JARBOE, L.R., GRABAR, T.B., YOMANO, L.P., SHANMUGAN, K.T., INGRAM, L.O.: Development of ethanologenic bacteria. Adv. Biochem. Engin/Biotechnol., 108, 2007, 237-261.

LEATHERS, T.D.: Bioconversion of maize residues to value-added coproducts using yeast - like fungi. FEMS Yeast Res., 3, 2003, 133-140.

MOSIER, S.N., HENDRICKSON, R., BREWER, M., HO, N., SEDLAK, M., DRESHEL, R., WELCH, G., DIEN, B.S., ADEN, A., LADISCH, R.M.: Industrial 
scale-up of pH-controlled liquid hot water pretreatment of corn fiber for fuel ethanol production. Appl. Biochem. Biotechnol., 125, 2005, 77-85.

NOUREDDINI, H., BYUN, J., YU, T.: Stagewise dilute-acid pretreatment and enzyme hydrolysis of distillers' grains and corn fiber. Appl. Biochem. Biotechnol., 2009 (in press).

PALMAROLA-ADRADOS, B., CHOTĚBORSKÁ, P., GALBE, M., ZACCHI, G.: Ethanol production from non-starch carbohydrates of wheat bran. Bioresour. Technol., 96, 2005, 843-850.

RÉCZEY, K., SZENGYEL, Z., EKLUND, R., ZACCHI, G.: Cellulase production by Trichoderma reesei. Bioresour. Technol., 57, 1996, 20-25.

SAHA, B.C.: Hemicellulose bioconversion. Ind. Microbiol. Biotechnol., 30, 2003, 279-291.

SCHELL, D.J., RILEY, C.J., DOWE, N., FARMER, J., IBSEN, K.N., RUTH, M.F., TOON, S.T., LUMPKIN, R.E.: A bioethanol process development unit: initial operating experiences and results with corn fiber feedstock. Bioresour. Technol., 91, 2004, 179-188.

SHIBANUMA, K., TAKAMINE, K., MASEDA, S., OSAKI, S., ABE, J., HIZUKURI, S.: Partial acid hydrolysis of corn fiber for the ethanol production of L-arabinose. J. Appl. Glycosci., 46, 1999, 249-256.

VAN MARIS, A.J.A., ABBOTT, D.A., BELLISSIMI, E., BRINK, J., KUYPER, M., LUTTIK, M.A.H., WISSELINK, H.W., SCHEFFERS, W.A., DIJKEN, J.P., PRONK, J.T.: Alcoholic fermentation of carbon sources in biomass hydrolysates by Saccharomyces cerevisiae: current status. Antonie van Leeuwenhoek, 90, 2006, 391-418.

ZHAO, J., WANG, M., YANG, Z.: Measurement of inhibitory effect of furfural and furfural alcohol using coupled redox mediators. Enzym. Microb. Tech., 37, 2005, 246-253. 